\begin{tabular}{c} 
International Journal of Engineering \& Technology, $7(4)(2018) 2789-2794$ \\
International Journal of Engineering \& Technology \\
SPC \\
$\begin{array}{c}\text { Website: } \text { www.sciencepubco.com/index.php/IJET } \\
\text { doi: } 10.14419 / \text { ijet.v7it.17149 } \\
\text { Research paper }\end{array}$ \\
\hline
\end{tabular}

\title{
Biophysical study regarding the effect of hydrogen sulfide on molecular structure and DNA of mammalian cornea
}

\author{
Amal E Ibrahim ${ }^{1 *}$, Sahar M. Awad ${ }^{2}$, Shimaa. M. Elshibly ${ }^{2}$, Gehan M. Kamal ${ }^{3}$

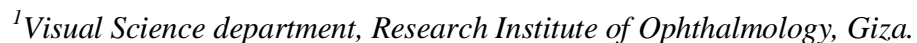 \\ ${ }^{2}$ Physics department, Faculty of Science (girls), Al-Azhar University, Cairo. \\ *Corresponding author E-mail: amal.ibrahim2011@outlook.com
}

\begin{abstract}
Background: Humans are affected by both exogenous and endogenous sources of hydrogen sulphide gas $\left(\mathrm{H}_{2} \mathrm{~S}\right)$. Its health effects depend on concentration and the duration of gas exposure. These hazards include-among many effects-eye irritation, tearing and inflammation. Objectives: Our study aimed to characterize the side effects induced in cornea due to H2S exposure by using by means of comet assay and Fourior Transformer Infrared Radiation (FTIR).

Materials and methods: sixty chinchilla rabbits were randomly grouped into four groups. Group one served as control. Animals were exposed to hydrogen sulphide gas with concentrations of, 90, 250 and $500 \mathrm{ppm}$. After exposure, animals were decapitated, and the eyes were enucleated from the eye globe. Their corneas were obtained by sectioning through ora serrate. Corneas were then kept frozen at $20^{\circ} \mathrm{C}$ for analysis by FTIR spectral and comet assay analysis

Results: NH-OH region changes revealed unusual interface/binding mechanism that related to different surrounding environment as well as co-existence of different formations and conformations in the system after exposure to $\mathrm{H}_{2} \mathrm{~S}$ gas. Moreover the exposure to $\mathrm{H}_{2} \mathrm{~S}$ gas has no effect on the $\mathrm{CH}$ stretching region that arising from lipid. All parameters of comet assay significantly increase $(\mathrm{p}<0.05)$ due to exposed doses. This increase is directly proportional to the increase in exposure level.

Conclusion: Hydrogen sulfide is a very toxic gas to cornea which is considered as window of the eye it has a serious effect on molecular structure and DNA of cornea. By better understanding its toxicity, we will be able to safely make use of its various benefits without the threat of harm looming over our heads.
\end{abstract}

Keywords:Hydrogen Sulphide; Eye; Cornea; Fourier Transformation; Comet Assay.

\section{Introduction}

Hydrogen sulfide $\left(\mathrm{H}_{2} \mathrm{~S}\right)$ is a toxic gas that is flammable, colourless gas and has a terrible smell. It can be produced naturally or artificially from volcanoes, sulfur springs, undersea vents, swamps, stagnant bodies of water, and in crude petroleum and natural gas. $\mathrm{H}_{2} \mathrm{~S}$ is also associated with municipal sewers and sewage treatment plants, swine containment and manure-handling operations, and pulp and paper operations[1]. $\mathrm{H}_{2} \mathrm{~S}$ can be the product of the natural digestive process[2]. It is responsible for the second highest number of occupational gas-related deaths, after carbon monoxide[3]. Ambient air concentrations of hydrogen sulfide from natural sources range between 0.00011 and $0.00033 \mathrm{ppm}$. Concentrations of hydrogen sulphide in urban areas are generally $<0.001$ ppm. Much higher levels (often exceeding $0.09 \mathrm{ppm}$ ) have been detected in communities living near natural sources of hydrogen sulfide or near industries releasing hydrogen sulphide[4]. Its health effects can vary depending on the level and duration of exposure. Repeated exposure can result in health effects occurring at levels that were previously tolerated without any effect[5]. According to Occupational Safety and Health Administration2017 (OSHA,) permissible exposure limit (PEL) is defined as the maximum air concentration you can be exposedwithout respiratory protection. The time Weighted Average is the average exposure over a specified period, usually hours in an eight hour period, 40 hour week, (TWA) is $10 \mathrm{ppm}$. Short term exposure limit(STEL) is the acceptable average exposure over a short period of time, usually based on a 15 minute is $15 \mathrm{ppm}$. Immediately dangerous to life and health (IDLH) is $100 \mathrm{ppm}$. The immediate death level which leads to immediately deathin 35 minutes is $1000 \mathrm{ppm}$. A list of current Threshold Limit Value(TLV) and biological exposure indices (PEIs) are published annually by the American Conference of Governmental Industrial Hygienists(ACGIH).According to ACGIH 2017, TWA andSTEL were $1 \mathrm{ppm}$ and5 ppm, respectively.It is found according to OSHA 2017 that prolonged exposure to hydrogen sulfide may cause tearing of the eyes at $2-5 \mathrm{ppm}$, by raising exposure to $50 \mathrm{ppm}$ slight conjunctivitis (gas eye) appear, and eye irritation at $100 \mathrm{ppm}$. Prolonged exposure to hydrogen sulfide, even at relatively low levels, may result in painful dermatitis and burning eyes as reported by Agency for Toxic Substances and Disease Registry 2014(ATSDR).

The present work was aimed to explore the molecular structure of rabbit's cornea and its DNA damage after exposure to different concentrations of hydrogen sulphide using infrared spectroscopy and comet assay.

\section{Materials and methods}

\subsection{Chemicals}

Hydrogen sulfide saturated solution was obtained from the ministry of environment, Cairo, Egypt. Other chemicals used in the 
experiments were obtained from Sigma Company (St. Louis, MO USA) with the highest purity grade available unless otherwise mentioned.

\subsection{Animals}

Sixty healthy Chinchilla rabbits of either sex, weighing $2-2.5 \mathrm{~kg}$ were randomly selected from the animal house facility at the Research Institute of Ophthalmology RIO, Giza, Egypt. The animals were kept separately under good ventilation and adequate standard diet. They were housed in special designed cages and maintained under constant air flow and illumination during the experimental periods. The animal was handled according to the ARVO (The Association for Research in Vision and Ophthalmology) statements and regulations for the use of animals in research. The rabbits were divided into 4 groups: control and 3 different exposed saturated $\mathrm{H}_{2} \mathrm{~S}$ solution of concentration 90,250 and $500 \mathrm{ppm}$, respectively.

\section{Hydrogen sulfide exposure}

Animals were exposed to $\mathrm{H}_{2} \mathrm{~S}$ gas for one hour in a specially designed chamber. The lid of the glass chamber has two ventilation holes to allow excess $\mathrm{H}_{2} \mathrm{~S}$ vapor and oxygen to flow. The concentration of the $\mathrm{H}_{2} \mathrm{~S}$ gas inside the chamber was monitored by the gas alert micro 5 gas detector (Brandt Instruments, Inc. LA, USA).

\section{Cornea preparation}

Animals were decapitated, and the eyes were enucleated from the eye globe. Their corneas were obtained by sectioning through ora serrate. Corneas were then kept frozen at $-20^{\circ} \mathrm{C}$ for analysis by FTIR spectral and comet assay analysis.

\section{FTIR spectroscopy measurements}

The corneas were weighted separately, and then crushed to powder by the aid of liquid nitrogen and mortar. The resulted corneal powder was freeze-dried for $24 \mathrm{~h}$ then mixed with potassium bromide $(\mathrm{KBr})$ powder $(80 \mathrm{mg} \mathrm{KBr}: 20 \mathrm{mg}$ cornea) to prepare the $\mathrm{KBr}$ disks for analyzed with FTIR measurement. FTIR spectra were recorded using Thermo Nicolet IS5 FTIR spectroscopy, USA in range $4000-1000 \mathrm{~cm}^{-1}$ at roomtemperature as briefly previously described by Eman and eman 2011[6].

\section{Single cell gel electrophoresis (comet assay)}

For the comet assay, $6 \mu \mathrm{L}$ of cornea homogenate was used and it is performed according to Nandhakumaret al., 2011 [7]

Statistical evaluation

Results were displayed as the mean $\pm \mathrm{SD}$. To obtain a comparison between groups, investigation of fluctuation was done by using the commercially available software program (SPSS-11 for windows, SPSS Inc., Chicago, Illinois, USA), where the significance level was set atP $<0.05$

\section{Results}

The spectra of FTIR results for normal and exposed corneas to specific concentration of $\mathrm{H}_{2} \mathrm{~S}$ that were recorded in the range
4000-1000 $\mathrm{cm}^{-1}$ are shown in fig.1.The detailed FTIR spectral analysis was performed in a three distinct frequency ranges,3800$3000 \mathrm{~cm}^{-1}$ (NH-OH region),3000-2800 $\mathrm{cm}^{-1}(\mathrm{CH}$ stretching region)and $1800-1000 \mathrm{~cm}^{-1}$ (fingerprintregion). Also amide I band (1700-1600 $\left.\mathrm{cm}^{-1}\right)$ which linked to fingerprint region and related to protein secondary structure was carefully analyzed.

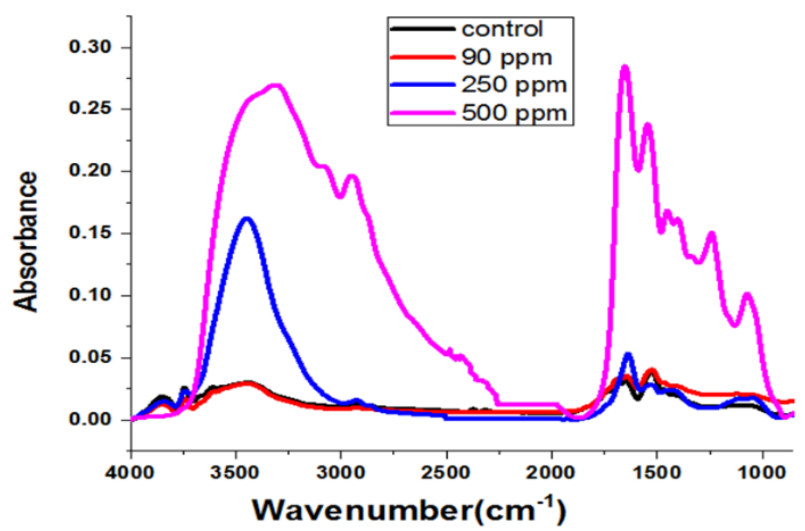

Fig. 1:Full Scale FTIR Spectra for Control and Exposed Corneas of Different Doses of $\mathrm{H}_{2} \mathrm{~S}$

\section{NH-OH region}

Fig (2) shows the NH-OH region $\left(3800-3000 \mathrm{~cm}^{-1}\right)$ of corneal tissues. The curve enhancement procedure; a combination of Fourier deconvolution and nonlinear curve fitting resolved the main peak of normal pattern into seven peaks as $3747 \pm 3,3607 \pm 2$, and $3513 \pm 2 \mathrm{~cm}^{-1}$ that corresponding to stretching $\mathrm{OH}\left({ }_{\mathrm{str}} \mathrm{OH}\right)$ labeled as (1), the peak at $3432 \pm 4 \mathrm{~cm}^{-1}$ related to $\mathrm{OH}$ asymmetric (asym $\left.\mathrm{OH}\right)$ that labeled as (2), $3326 \pm 3$ related to $\mathrm{NH}$ asymmetric $(\operatorname{asym} \mathrm{NH})$ labeled as (3), $3218 \pm 1 \mathrm{~cm}^{-1}$ related to $\mathrm{OH}$ symmetric $\left({ }_{\text {sym }} \mathrm{OH}\right)$ labeled as (4), and $3162 \pm 1 \mathrm{~cm}^{-1}$ which corresponding to NH symmetric $\left({ }_{\text {sym }} \mathrm{NH}\right)$ labeled as (5) as given in table (1) and previously mentioned by Aly 2011[8].

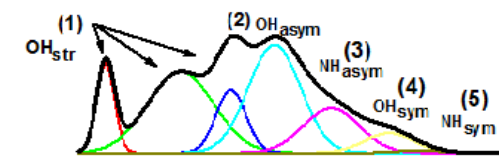

control
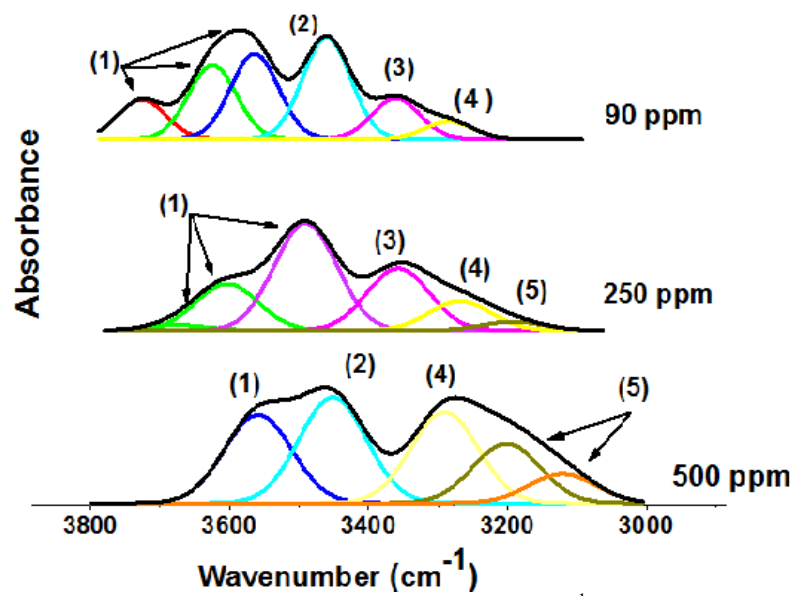

Fig. 2: Analysis of $\mathrm{NH}-\mathrm{OH}$ Region $\left(3800-3000 \mathrm{Cm}^{-1}\right)$ for Control and All Corneas Exposed to Different Concentration of $\mathrm{H}_{2} \mathrm{~S}$.

Table 1:NHOH Region (3800-3000 $\mathrm{Cm}^{-1}$ ) of Corneal Tissues for Control and All Groups Exposed to Different Concentration of $\mathrm{H}_{2} \mathrm{~S}$

\begin{tabular}{|c|c|c|c|c|c|c|c|c|c|}
\hline & $(1)_{\mathrm{Str}} \mathrm{OH}$ & & & & & (2) $\mathrm{OH}_{\text {asym }}$ & (3) $\mathrm{NH}_{\text {asym }}$ & (4) $\mathrm{OH}_{\text {sym }}$ & (5) $\mathbf{N H}_{\text {sym }}$ \\
\hline Control & $3747 \pm 339 \pm 11$ & & $\begin{array}{l}3607 \pm 2 \\
146 \pm 10\end{array}$ & $\begin{array}{l}3513 \pm 2 \\
65 \pm 6\end{array}$ & & $\begin{array}{l}3432 \pm 4 \\
115 \pm 10\end{array}$ & $\begin{array}{l}3326 \pm 3 \\
124 \pm 7\end{array}$ & $\begin{array}{l}3218 \pm 1 \\
108 \pm 2\end{array}$ & $\begin{array}{l}3162 \pm 1 \\
95 \pm 6\end{array}$ \\
\hline 90 ppm & $3729 \pm 2^{\dagger} 93 \pm 8^{\dagger}$ & & $\begin{array}{l}3610 \pm 3 \\
93 \pm 11^{\dagger}\end{array}$ & $\begin{array}{l}3543 \pm 3^{\dagger} \\
93 \pm 9^{\dagger}\end{array}$ & & $\begin{array}{l}3425 \pm 3^{\dagger} \\
93 \pm 9^{\dagger}\end{array}$ & $\begin{array}{l}3310 \pm 3^{\dagger} \\
99 \pm 8^{\dagger}\end{array}$ & $\begin{array}{l}3225 \pm 1^{\dagger} \\
96 \pm 10\end{array}$ & \\
\hline 250 & & $3684 \pm 1$ & $33^{r} 59 \pm 2^{\dagger}$ & & $3478 \pm 3$ & & $3313 \pm 2^{\dagger}$ & $3232 \pm 3^{\dagger}$ & $3148 \pm 2^{\dagger}$ \\
\hline
\end{tabular}




\begin{tabular}{|l|l|l|l|l|l|l|l|l|l|l|l|l}
\hline ppm & & $128 \pm 5$ & $109 \pm 6^{\dagger}$ & & $118 \pm 8$ & & $118 \pm 9^{\dagger}$ & $118 \pm 9^{\dagger}$ & $115 \pm 7^{\dagger}$ \\
\hline $\mathbf{5 0 0}$ & & & & $\begin{array}{l}3558 \pm 4^{\dagger} \\
114 \pm 8^{\dagger}\end{array}$ & & $\begin{array}{l}3451 \pm 2^{\dagger} \\
114 \pm 5\end{array}$ & $3291 \pm 1^{\dagger}$ & $3201 \pm 2$ \\
ppm & & & & $3120 \pm 1^{\dagger}$ \\
$114 \pm 6^{\dagger}$ & $114 \pm 10$ \\
\hline
\end{tabular}

First line in each cell indicates the vibrational frequency, while second line reflects the bandwidth.

${ }^{\dagger}$ statistical significant $(\mathrm{p}<0.05)$

After exposure to different concentrations of $\mathrm{H}_{2} \mathrm{~S}$ gas, there was remarked change in the counter of $\mathrm{NH}-\mathrm{OH}$ region. The stretching $\mathrm{OH}\left({ }_{\mathrm{str}} \mathrm{OH}\right)$ in the control rabbit have three bands discernible at $3747 \pm 3,3607 \pm 2$ and $3513 \pm 2 \mathrm{~cm}^{-1}$. Due to exposure to $90 \mathrm{ppm}$ and $250 \mathrm{ppm}$ of $\mathrm{H}_{2} \mathrm{~S}$, the same observation can be noticed; there are three peaks but with different characteristic band positions and bandwidth as compared with the control pattern. Finally, at higher dose $-500 \mathrm{ppm}$ - there are restriction in the vibrational motion of the NH-OH bands and one peak was detected at $3558 \pm 4 \mathrm{~cm}^{-1}$ with significant increase in both band position and bandwidth. For the $\mathrm{OH}$ asymmetric $\left({ }_{\text {asym }} \mathrm{OH}\right)$ mode of vibration, it was found to be sensitive to the exposure to the specific concentrations of $\mathrm{H}_{2} \mathrm{~S}$ when compared to control pattern. It has significant decrease in band position after exposure to $90 \mathrm{ppm}$,and significantly increased at $500 \mathrm{ppm}$. This mode of vibration has been restricted at 250 $\mathrm{ppm}$. Again, The stretching $\mathrm{NH}$ asymmetric $\left({ }_{\text {asym }} \mathrm{NH}\right)$ vibrational mode can be related directly to the exposed doses of $\mathrm{H}_{2} \mathrm{~S}$; its band position as well as bandwidth were decreased as the exposure dose increased and finally, it was restricted due to exposure to the highest dose of $\mathrm{H}_{2} \mathrm{~S}$ (500 ppm). The stretching $\mathrm{OH}$ symmetric $\left({ }_{\text {sym }} \mathrm{OH}\right)$ band is sensitive to $\mathrm{H}_{2} \mathrm{~S}$ exposure. It was located at $3218 \pm 1 \mathrm{~cm}^{-1}$ in control pattern, then its band position directly increased with the exposure dose of $\mathrm{H}_{2} \mathrm{~S}$. No change in its bandwidth was noticed between groups. Stretching NH symmetric $\left({ }_{\operatorname{sym}} \mathrm{NH}\right)$ vibrational motion was restricted at $90 \mathrm{ppm}$. As the exposure dose increased to $250 \mathrm{ppm}$ there was a significant reduction in its band position. For the highest dose; $500 \mathrm{ppm}$, it has been splitted to two peaks with reduced vibrational frequency as given in table (1).

$\mathrm{CH}$ stretching region

The $\mathrm{CH}$ stretching region of normal corneas and those exposed to $\mathrm{H}_{2} \mathrm{~S}$ gas is shown in fig. (3). The $\mathrm{CH}$ vibrations indicate the presence of four absorption bands at $2963 \pm 2 \mathrm{~cm}^{-1}$ with bandwidth $28 \pm 5 \mathrm{~cm}^{-1}, 2925 \pm 3 \mathrm{~cm}^{-1}$ with bandwidth $44 \pm 6 \mathrm{~cm}^{-1}, 2879 \pm 3 \mathrm{~cm}^{-1}$ with bandwidth $50 \pm 9 \mathrm{~cm}^{-1}$, and $2855 \pm 3 \mathrm{~cm}^{-1}$ with corresponding band width $40 \pm 6 \mathrm{~cm}^{-1}$. These bands assigned as asym $\mathrm{CH}_{3}$, asym $\mathrm{CH}_{2}$, ${ }_{\text {sym }} \mathrm{CH}_{3}$ and ${ }_{\text {sym }} \mathrm{CH}_{2}$ respectively as mentioned by Severcan et al., 2000[9]. The general observation that can be concluded from this figure and table (2) is that exposure to $\mathrm{H}_{2} \mathrm{~S}$ gas in the concentration range 90 to $500 \mathrm{ppm}$ does not affect the vibrational motion of the $\mathrm{CH}$ bond.

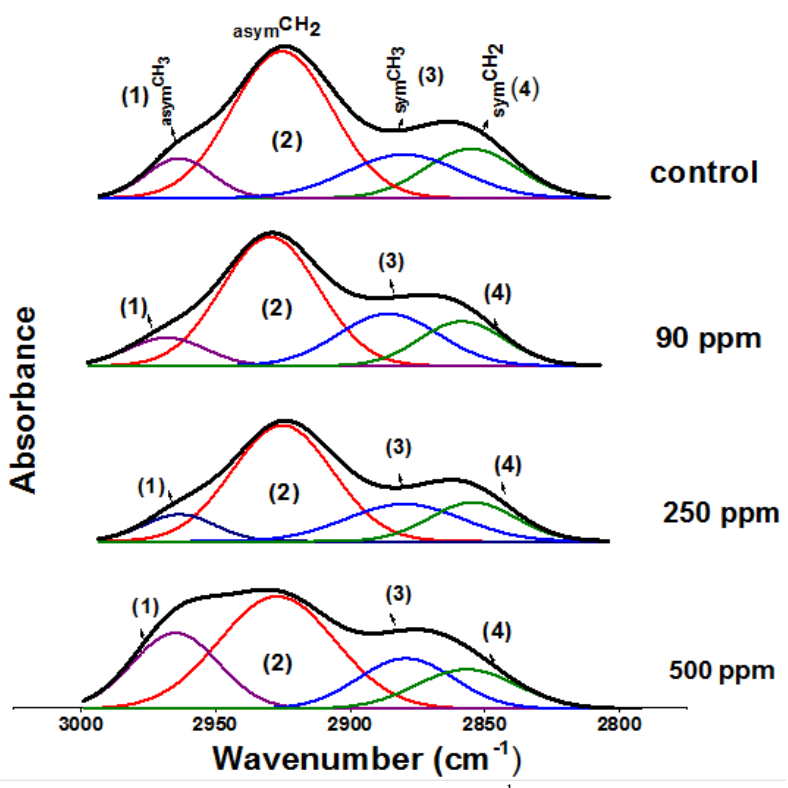

Fig. 3: Analysis of $\mathrm{CH}$ Region (3000-2800 $\left.\mathrm{Cm}^{-1}\right)$ Forcontrol and Allcorneas Exposed to Different Concentration of $\mathrm{H}_{2} \mathrm{~S}$.
Table 2: CH Region (3000-2800 $\mathrm{cm}^{-1}$ ) for Control andAllcorneas Exposed to Different Concentration of $\mathrm{H}_{2} \mathrm{~S}$

\begin{tabular}{lllll}
\hline & asym $\mathbf{C H}_{\mathbf{3}}$ & asym $\mathbf{C H}_{\mathbf{2}}$ & asym $_{\mathbf{C H}}$ & asym $\mathbf{C H}_{\mathbf{2}}$ \\
\hline \multirow{2}{*}{ Control } & $2963 \pm 2$ & $2925 \pm 3$ & $2879 \pm 3$ & $2855 \pm 3$ \\
& $28 \pm 5$ & $44 \pm 6$ & $50 \pm 9$ & $40 \pm 6$ \\
$\mathbf{9 0} \mathbf{~ p p m}$ & $2963 \pm 2$ & $2925 \pm 2$ & $2882 \pm 2$ & $2854 \pm 2$ \\
& $33 \pm 4$ & $42 \pm 2$ & $44 \pm 5$ & $37 \pm 5$ \\
$\mathbf{2 5 0} \mathbf{~ p p m}$ & $2963 \pm 2$ & $2924 \pm 1$ & $2879 \pm 3$ & $2854 \pm 2$ \\
& $31 \pm 2$ & $44 \pm 1$ & $51 \pm 8$ & $38 \pm 6$ \\
$\mathbf{5 0 0}$ & $2961 \pm 2$ & $2927 \pm 3$ & $2883 \pm 3$ & $2860 \pm 3$ \\
& $34 \pm 4$ & $46 \pm 3$ & $38 \pm 6$ & $40 \pm 4$ \\
\hline
\end{tabular}

First line in each cell indicates the vibrational frequency,while second line reflects the bandwidth.

Fingerprint Region

The third region of the FTIR in Fig (4) is the fingerprint region $\left(1800-1000 \mathrm{~cm}^{-1}\right)$. Analysis of control pattern revealed the presence of 9 bands at $1727 \pm 2,1646 \pm 3,1520 \pm 2,1457 \pm 3,1388 \pm 3$ $, 1335 \pm 4,1289 \pm 2,1151 \pm 2$ and $1070 \pm 1 \mathrm{~cm}^{-1}$ and can be assigned as (1) ester $\mathrm{C}=\mathrm{O}$,(2) amide I, (3) amide II, (4) $\mathrm{CH}_{2}$ bending,(5) stretching sym $_{\text {COO-, }}$ (6) deformCH $\mathrm{H}_{3}$, (7) stretching asym $_{\mathrm{PO}_{2}}(8)$ stretching asym $\mathrm{COOC}$ and (9) stretching ${ }_{\text {sym }} \mathrm{PO}_{2}$ as mentioned byAly $2011[8]$.

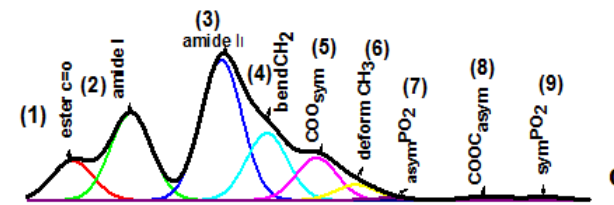

control

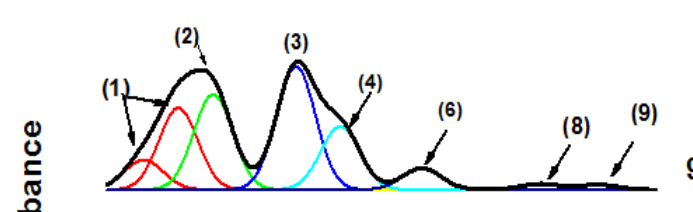

90 ppm

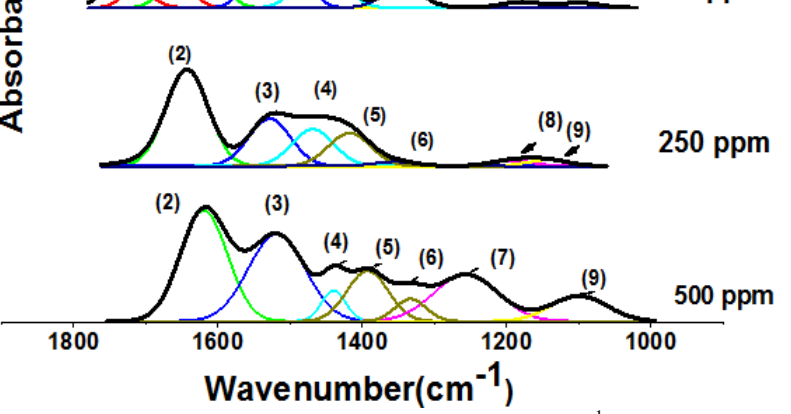

Fig. 4: Analysis of Fingerprint Region (1800-1000 $\mathrm{cm}^{-1}$ ) for Control and All Corneas Exposed to Different Concentration of $\mathrm{H}_{2} \mathrm{~S}$.

After exposure to 90 and $250 \mathrm{ppm}$ of $\mathrm{H}_{2} \mathrm{~S}$, the vibrational motion of ester $\mathrm{C}=\mathrm{O}$ that labeled as (1) was increased and splitted in 90 $\mathrm{ppm}$ group, and restricted at $500 \mathrm{ppm}$. Amide I that labeled as (2) and located between $1700-1600 \mathrm{~cm}^{-1}$ attributed to $\mathrm{C}=\mathrm{O}$ stretching of carboxylic acid of amino acid, show increased band position and bandwidth; a detailed analysis is provided in the next section. Amide II band that labeled as (3) and appears at $1520 \pm 2 \mathrm{~cm}^{-1}$ in normal pattern was increased in wavenumber. This increase is directly proportional with the increased dose of $\mathrm{H}_{2} \mathrm{~S}$. No change in bandwidth except for $500 \mathrm{ppm}$.

The absorption band at $1457 \pm 3 \mathrm{~cm}^{-1}$ in normal pattern represents the $\mathrm{CH}_{2}$ bending and labeled as (4) in fig. (4). It shows no significant changes in its band position and no change in its bandwidth due to exposed to $\mathrm{H}_{2} \mathrm{~S}$ except for $500 \mathrm{ppm}$. On the other hand, the absorption at $1388 \pm 3 \mathrm{~cm}^{-1}$ which represents the $\mathrm{COO}$ symmetric mode of vibration (labeled as 5) show significant increase in its band position as well as its bandwidth for 250 and 500 ppm exposed groups. It was restricted in $90 \mathrm{ppm}$ exposed group 
$\mathrm{CH}_{3}$ deformation mode that labeled as (6) and appeared at $1335 \pm$ $5 \mathrm{~cm}^{-1}$ in control pattern was not significantly changed due to the exposure to different doses of $\mathrm{H}_{2} \mathrm{~S}$. The absorption of at $1289 \pm 2$ $\mathrm{cm}^{-1}$ in normal pattern can be assigned as $\mathrm{PO}_{2}$ asymmetric that labeled as (6). This band restricted in 90 and $250 \mathrm{ppm}$ exposed groups and detected in $500 \mathrm{ppm}$ exposed group but with reduced band position. The COOC asymmetric band labeled as (8) that detected at $1151 \pm 2 \mathrm{~cm}^{-1}$ in the control pattern, shows fluctuated changes due to exposure to 90 and $250 \mathrm{ppm}$ then, restricted due to exposure to $500 \mathrm{ppm}$.

On other hand the $\mathrm{PO}_{2}$ symmetric mode of vibration that labeled as (9) and discernible at $1070 \pm 1 \mathrm{~cm}^{-1}$ in the control pattern was found to react with the $\mathrm{H}_{2} \mathrm{~S}$ gas non-specifically; there was increased in band position at $90 \mathrm{ppm}$ and $250 \mathrm{ppm}$ groups while reduced at $500 \mathrm{ppm}$. Its bandwidth was increased at $500 \mathrm{ppm}$ as given in the table (3).

Table 3: Fingerprint Region Assignment to Control and Different Exposed Groups to $\mathrm{H}_{2} \mathrm{~S}$

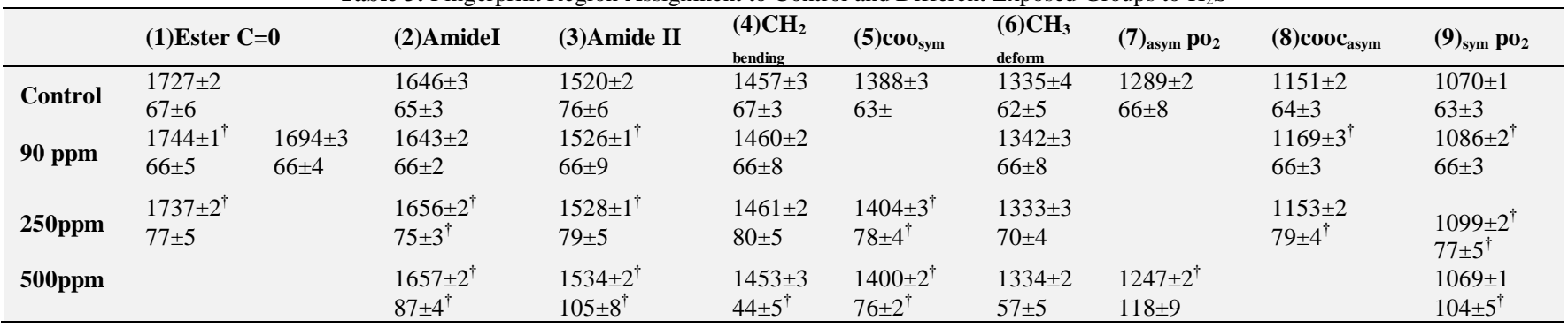

First line in each cell indicates the vibrational frequency, while second line reflects the bandwidth.

'statistical significant $(\mathrm{p}<0.05)$.

Amide I band

The amide I absorption is mainly associated with protein amide $\mathrm{C}=\mathrm{O}$ stretching vibration. Fig. 4 display the component band of amide I, which are obtained by curve fitting analysis. Four estimated bands were resolved in normal pattern. The bands were detected $1673 \pm 3 \mathrm{~cm}^{-1}$ ( $\beta$ - turn structure, labeled as 1$), 1652 \pm 2$ $\mathrm{cm}^{-1}(\alpha-$ helix, labeled as $r), 1637 \pm 2 \mathrm{~cm}^{-1}$ and $1624 \pm 3 \mathrm{~cm}^{-1}(\beta-$ sheet, labeled as $r$ ) as previously described byYang et al., 2005 [10]

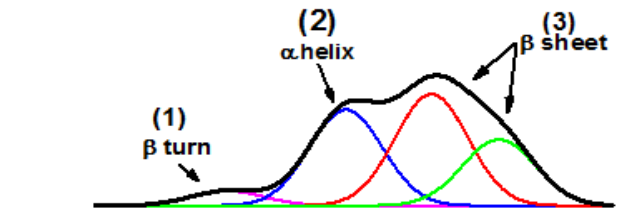

control

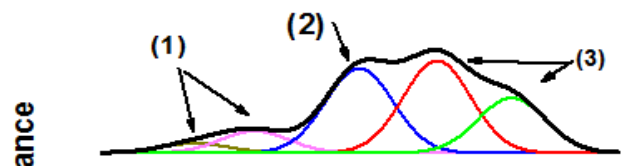

$90 \mathrm{ppm}$

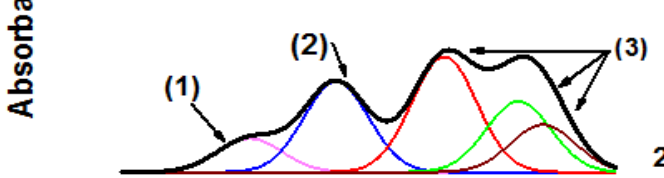

250 ppm

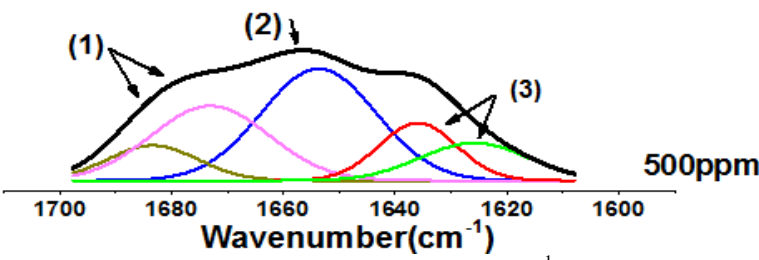

Fig. 5: Analysis of Amide I Region (1700-1600 $\mathrm{Cm}^{-1}$ ) for Control and All Corneas Exposed to Different Concentration of $\mathrm{H}_{2} \mathrm{~S}$.

The contour of the amide I band was affected by the $\mathrm{H}_{2} \mathrm{~S}$ gas exposure. This change was concomitant with variation in $\beta$-turns and $\beta$-sheet structures. According to table (5), $\beta$-turns content was directly increased as the $\mathrm{H}_{2} \mathrm{~S}$ exposed dose increased. In the same context, $\beta$-sheet was decreased due to exposure to 250 and $500 \mathrm{ppm}$. The distribution of normal protein secondary structure components (that were calculated as the area percentage) are $5 \pm 2$ $\%$ for $\beta$ turn, $35 \pm 5 \%$ for $\alpha$ helix and $61 \pm 9 \%$ for $\beta$ sheet.
Table 4:Protein Secondary Structure Changes of Corneas Expressed as Percentage Area of B-Turn, A-Helix and B-Sheet for Control and All Groups Exposed to Different Concentration of $\mathrm{H}_{2} \mathrm{~S}$

\begin{tabular}{llll}
\hline Groups & $\beta$-Turns $\%$ & $\alpha-$ helix $\%$ & $\beta$ - Sheet $\%$ \\
\hline Control & $5 \pm 2$ & $3 \leqslant \pm 5$ & $61 \pm 9$ \\
$90 \mathrm{ppm}$ & $12 \pm 3^{\dagger}$ & $32 \pm 3$ & $56 \pm 8$ \\
$250 \mathrm{ppm}$ & $10 \pm 2^{\dagger}$ & $r 5 \pm 6$ & $5 \cdot \pm 8$ \\
$500 \mathrm{ppm}$ & $36 \pm 4^{\dagger}$ & $39 \pm 5$ & $25 \pm 7^{\dagger}$ \\
\hline
\end{tabular}

Statistically significant

Comet assay

The genetic material within the corneal tissue was studied by the Comet assay and the results are given in fig. (6).
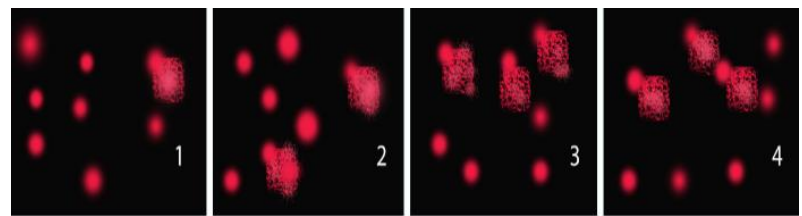

Fig. 6:Representative Photographs of Comet Assay of Cornea Cells for Control and Exposed Cornea for Different Concentration of $\mathrm{H}_{2} \mathrm{~S}$ 90, 250 and $500 \mathrm{Ppm}$

In control group the DNA was tightly compressed and maintained the circular disposition of the normal nucleus. After exposure to the specific doses of $\mathrm{H}_{2} \mathrm{~S}$, the profile of the nuclear DNA was altered with the appearance of a fluorescent streak extending from the nucleus as appeared for all doses comprising the comet in different percentages. A variety of symmetrical and densitometric parameters are provided by the image analysis software, which allows an estimation of the amount of DNA in the head and tail region. Because the tail length and its density reflect the number of single-strand breaks in the DNA, the percentage of DNA in the tail provides a quantitative measure of the damaged DNA.

The percentage of tailed nuclei, tail length, tail DNA and tail moment in control group and treated groups are given in table (5).

Table 5:Percentage of Tailed Nuclei, Tail Length, Tail DNA and Tail Moment of Exposing Corneas to Different Concentration of $\mathrm{H}_{2} \mathrm{~S}$ Compared to Control

\begin{tabular}{lllll}
\hline Groups & $\begin{array}{l}\text { \% Tailed } \\
\text { cells }\end{array}$ & $\begin{array}{l}\text { Tail } \\
\text { length }(\boldsymbol{\mu m})\end{array}$ & $\begin{array}{l}\text { \% Tail } \\
\text { DNA }\end{array}$ & $\begin{array}{l}\text { Tail mo- } \\
\text { ment(Units) }\end{array}$ \\
\hline $\begin{array}{l}\text { Con- } \\
\text { trol }\end{array}$ & $3 \pm 1$ & $0.92 \pm \bullet .03$ & $1.29 \pm 0.06$ & $1.19 \pm 0.06$ \\
$\begin{array}{l}\mathbf{9 0 p p m} \\
\mathbf{2 5 0}\end{array}$ & $6 \pm 1^{\dagger}$ & $1.69 \pm 0.07^{\dagger}$ & $1.82 \pm 0.05^{\dagger}$ & $3.08 \pm 0.1^{\dagger}$ \\
$\mathbf{p p m}$ & $12 \pm 2^{\dagger}$ & $2.28 \pm 0.1^{\dagger}$ & $2.68 \pm 0.2^{\dagger}$ & $6.11 \pm 0.5^{\dagger}$ \\
$\begin{array}{l}\mathbf{5 0 0} \\
\text { ppm }\end{array}$ & $17 \pm 2^{\dagger}$ & $3.05 \pm 0.1^{\dagger}$ & $3.62 \pm 0.1^{\dagger}$ & $11.04 \pm 1^{\dagger}$ \\
\hline
\end{tabular}


'Statistically significant.

The tail length measured from the middle of the nucleus to the end of the tail has smallest value in control group $0.92 \pm \cdot .03 \mu \mathrm{m}$ (which indicate natural DNA damage). The length increases (statistically increase $p<0.05$ ) with doses to reach maximum value $3.05 \pm 0.1 \mu \mathrm{m}$ in $500 \mathrm{ppm}$. All parameters of comet assay significantly increase due to exposed doses. This increase is directly proportional to the increase in exposure level as given in table (5).

\section{Discussion}

It is possible to divide the mid-infrared region in other smaller spectral regions where strong absorption bands can be associated to specific components. Those regions are: fatty acids region, amide region, assigned primarily to proteins and peptides; mixed region, assigned to carboxylic groups of proteins, free amino acids; and the polysaccharide region. Besides, there are other spectral regions such as the one that is relevant to RNA, DNA and phospholipid content [11].

The results of this study revealed that the NH-OH region of FTIR spectra (Fig.4) of the corneal tissue is sensitive to exposure of different doses of $\mathrm{H}_{2} \mathrm{~S}$.

$\mathrm{NH}-\mathrm{OH}$ region changes revealed unusual interface/binding mechanism that related to different surrounding environment as well as co-existence of different formations and conformations in the system after exposure to $\mathrm{H}_{2} \mathrm{~S}$ gas. Changes in $\mathrm{OH}$ modes indicate the formation of hydrogen bonds with different structural states[12]. Moreover the exposure to $\mathrm{H}_{2} \mathrm{~S}$ gas has no effect on the $\mathrm{CH}$ stretching region that arising from lipid [13].

The noticeable fluctuation changes in the fingerprint region recognized to an oxidative stress after exposure to different doses of $\mathrm{H}_{2} \mathrm{~S}$ and increase the stress with the dose. The changing in asym$\mathrm{PO}_{2}{ }^{-}$and ${ }_{\text {sym }} \mathrm{PO}_{2}$ band is indicated to disorder in the genetic material or phospholipids that involved in the structure of corneal tissues which are highly specialized layers.

FTIR spectroscopy has been used to study the secondary structure composition, structural dynamics, conformational changes structural stability and aggregation of proteins .In the amide I region (1700-1600 $\mathrm{cm}-1)$, each type of secondary structure gives rise to a somewhat different $\mathrm{C}=\mathrm{O}$ stretching frequency due to unique molecular geometry and hydrogen bonding pattern[14].

For proteins to perform these important tasks, they must fold to their proper, unique three-dimensional structure. Poor protein folding and insolubility lead to inefficient functional protein. There are three common secondary structures in proteins, namely $\alpha$ - helix, $\beta$-turns and $\beta$-sheets. $\beta$-turns are conformations that enable protein to adopt globular structures, and their formation is often rate limiting for folding. They are the smallest type of the secondary structure, joining other elements of secondary structures as $\alpha$ - helix and $\beta$-sheets, and abruptly change the direction of the polypeptide chain. The formed $\beta$-turn structure may serve as a nucleation site for folding/refolding of proteins. $\beta$-sheets are another protein secondary structure conformation; although the importance of $\beta$-sheets in the folded structures of

Proteins has long been recognized, there is growing interest of molecular interactions among $\beta$-sheets. $\beta$ - sheets have dual functions; in normal tissue, they are important for biological activities, and they are involved in many diseases such as cancer. Intermolecular $\beta$-sheet interactions (band $<1620 \mathrm{~cm}^{-1}$ ) are associated with bimolecular recognition, protein quaternary structure, proteinprotein interactions and peptide and protein aggregation. While, intramolecular $\beta$-sheet interactons (band between 1630-1620 $\mathrm{cm}^{-1}$ ) are associated with protein folding[13]. Thus, vibrational spectra, as those of the FTIR spectra, were directly related to the structural features of molecules.

In our study $\beta$ - sheet the strands of polypeptide are stretched out and lie either parallel or antiparallel to one another and hydrogen bonds forms randomly between the strands after exposure to $\mathrm{H}_{2} \mathrm{~S}$. The domination of $\beta$-turns content which directly proportion to decrease the content of $\beta$ - sheet indicates that corneas protein turns to insoluble and more folded corneal protein which gives the impetus that the proteins become aggregated.

The comet assay for corneal cells has been applied to investigate the potential genotoxicity of $\mathrm{H}_{2} \mathrm{~S}$ [15].

The degree of DNA damage observed in control groupindicated the $\%$ tailed cells might be explained by the fact that about 10000 oxidation hits to DNA per cell have been estimated to occur per day within the human body, and more than 35 different forms of oxidized bases are found in DNA [16].

The effect of $\mathrm{H}_{2} \mathrm{~S}$ induces p53 (is a well- defined tumor suppressor gene)that has been mapped and characterized in the normal cornea across different species p53 plays a role in many abnormal types of cell proliferation, in apoptosis in response to DNA injury and in the prevention of replication of genomes that have suffered DNA damage [17] $\mathrm{H}_{2} \mathrm{~S}$ causes cell cycle alteration and formation of micronuclei (MN). The formation of $\mathrm{MN}$ represents fragments of the chromosome or whole chromosomes resulting from clastogenic events and as such is considered as a reliable marker for DNA damage [18]. Also, $\mathrm{H}_{2} \mathrm{~S}$ triggers important markers of apoptosis, including the release of cytochrome $\mathrm{c}$ from the mitochondrial membrane into the cytoplasm and also the translocation of apoptosis regulator Bax gene from cytosol to the mitochondria [19].Bax play an important role in the regulation of corneal epithelial renewal in adult and during development of cornea [20].

\section{Conclusion}

Hydrogen sulfide is a very toxic gas to cornea which is considered as window of the eye it has a serious effect on infra structure and DNA of cornea. By better understanding its toxicity, we will be able to safely make use of its various benefits without the threat of harm looming over our heads.

\section{References}

[1] Xia. Daniel, He. Zhiyong Hydrogen Sulfide (H2S) in the Permian Basin.Annual Convention and Exhibition, Houston, Texas, United States, April 2-5, $2017 * *$ Data pages (C) 2017 Serial rights given by author.

http://www.searchanddiscovery.com/pdfz/documents/2017/10950xi a/ndx_xia.pdf.htm.

[2] K. Pope, T. So, J. Crane, and N. Bates, Ambient geothermal hydrogen sulfide exposure and peripheral neuropathy, Neurotoxicology (2017), 60 $10-15$ https://www.ncbi.nlm.nih.gov/pmc/articles/PMC5447475/.https://d oi.org/10.1016/j.neuro.2017.02.006

[3] L. Guidotti Hydrogen sulfide: advances in understanding human toxicity, International journal of toxicology (2010), 29, 569-581. http://journals.sagepub.com/doi/pdf/10.1177/1091581810384882.ht tps://doi.org/10.1177/1091581810384882.

[4] K. Jones, Case studies of hydrogen sulphide occupational exposure incidents in the UK, Toxicology letters (2014), 231, 374-377. https://www.sciencedirect.com/science/article/pii/S0378427414012 922.https://doi.org/10.1016/j.toxlet.2014.08.005.

[5] R. Tiwari, Occupational health hazards in sewage and sanitary workers, Indian journal of occupational and environmental medicine (2008)12, 112-115 http://www.ijoem.com/article.asp?issn=00195278;year=2008; volu me $=12 ;$ issue $=3 ;$ spage $=112$; epage $=115$; aulast $=$ Tiwari.https: $/ /$ doi.org /10.4103/0019-5278.44691

[6] M.A. Eman and S.A. Eman, Evaluation of prolonged adherent with benzalkonium chloride on corneal protein secondary structure thatassessed by Fourier transform infrared spectroscopy Journal of American Science (2011)7(12)758764.https://www.researchgate.net/publication/266886489 Evaluati on_of_prolonged_adherent_with_benzalkonium_chloride_on_corne al_protein_secondary_structure_that_assessed_by_Fourier_transfor m_infrared_spectroscopy.

[7] S. Nandhakumar, S. Parasuraman, M. Shanmugam, R. Rao, P. Chand, and V. Bhat, Evaluation of DNA damage using single-cell gel electrophoresis (Comet Assay). Journal of pharmacology \&pharmaco-therapeutics (2011)2, 107. https://www.ncbi.nlm.nih.gov/pmc/articles/PMC3127337/. 
[8] M. Aly Effect of different concentration of Benzalkonium Chloride on the cornea, journal of amierican science (2011) 7, 697-703 http://www.jofamericanscience.org/journals/amsci/am0704/97_529 8am0704_697_703.pdf.

[9] F. Severcan, N. Toyran, N. Kaptan, and B. Turan, Fourier transformerinfrared study of effect of diabetes on rat liver and heart tissues in the $\mathrm{CH}$ region, Talanta (2000) 53, 55-59. http://europepmc.org/abstract/MED/18968088.https://doi.org/10.10 16/S0039-9140(00)00379-9.

[10] Y. Yang, J. Sulé-Suso, D. Sockalingum, G. Kegelaer, M. Manfait, and J. El Haj,Study of tumor cell invasion by Fourier transform infrared microspectroscopy, Biopolymers (2005) 78, 311-317. https://www.ncbi.nlm.nih.gov/pubmed/15898120.https://doi.org/10. 1002/bip.20297.

[11] Y. Lin, J. Li, T. Cheng, FT-IR and Raman vibrational microspectroscopies used for spectral biodiagnosis of human tissues, Journal of Spectroscopy (2007) 21, 130.https://www.hindawi.com/journals/jspec/2007/278765/abs/.https ://doi.org/10.1155/2007/278765.

[12] A. Morsy, M. Aly, M. Ibrahim, S. Mahmoud, and M. Kamal, Potential hazards of glyphosate on rabbit retina, Journal of the Arab Society for Medical Research (2017)12,92.http://new.asmr.eg.net/article.asp?issn=16874293;year $=2017 ;$ volume $=12 ;$ issue $=2 ;$ spage $=92 ;$ epage $=98 ;$ aulast=Morsy;type $=3$. https://doi.org/10.4103/jasmr.jasmr 10_17.

[13] M. Gamal, M. Aly, S. Mahmoud, S. Talaat, M. Sallam, FTIR assessment of the effect of Ginkgo biloba leave extract (EGb 761) on mammalian retina, Cell biochemistry and biophysics (2011) 61,169-177.

https://www.ncbi.nlm.nih.gov/pubmed/?term=ftir13)\%09Gamal+M $. \% 2 \mathrm{C}+\mathrm{Aly}+\mathrm{M} . \% 2 \mathrm{C}+$ Mahmoud $+\mathrm{S} . \% 2 \mathrm{C}+$ Talaat $+\mathrm{S} .+\mathrm{and}+$ Sallam+ M.\%2C+(2011)\%2CFTIR+assessment+of+the+effect+of+Ginkgo+ bi-

loba+leave+extract+(EGb+761)+on+mammalian+retina\%2C+Cell +biochemistry+and+biophysics\%2C+61\%2C169-177.

[14] J. Kong, S. Yu, Fourier transform infrared spectroscopic analysis of protein secondary structures, ActabiochimicaetbiophysicaSinica (2007) 39, 549-559. https://www.ncbi.nlm.nih.gov/pubmed/17687489.https://doi.org/10. 1111/j.1745-7270.2007.00320.x.

[15] M. El-Sayed, M. Aly, Toxoplasma gondii infection can induce retinal DNA damage: an experimental study, International journal of ophthalmology (2014) 7 431-436. https://www.ncbi.nlm.nih.gov/pmc/articles/PMC4067654/.

[16] B .Halliwell, Why and how should we measure oxidative DNA damage in nutritional studies? How far have we come?, The American journal of clinical nutrition (2000)72, 1082-1087. https://academic.oup.com/ajcn/article/72/5/1082/4729758.https://do i.org/10.1093/ajen/72.5.1082.

[17] Y. Tendler, R. Pokroy, A. Panshin, and G. Weisinger,protein subcellular localization and apoptosis in rodent corneal epithelium cell culture following ultraviolet irradiation, International journal of molecular medicine (2013) 31, 540-546. https://www.spandidospublica-

tions.com/ijmm/31/3/540.https://doi.org/10.3892/ijmm.2013.1247.

[18] M. Fenech, and A. Morley, Kinetochore detection in micronuclei An alternative method for measuring chromosome loss, Mutagenesis (1989)2, 98-104 https://www.ncbi.nlm.nih.gov/pubmed/2659933.https://doi.org/10.1 093/mutage/4.2.98

[19] R. Baskar, L. Li and K. Moore,Hydrogen sulfide-induces DNA damage and changes in apoptotic gene expression in human lung fibroblast cells, The FASEB Journal (2007) 21, 247 255.https://www.ncbi.nlm.nih.gov/pubmed/17116745.https://doi.or $\mathrm{g} / 10.1096 / \mathrm{fj} .06-6255 \mathrm{com}$.

[20] S. Roberts, S. Thomas and C. Dorman, Gene expression changes following acute hydrogen sulfide $(\mathrm{H} 2 \mathrm{~S})$-induced nasal respiratory epithelial injury, Toxicological pathology (2008), 36, 560-567. http://journals.sagepub.com/doi/10.1177/0192623308317422.https:/ /doi.org/10.1177/0192623308317422. 